\title{
LAS FUNCIONES DEL LENGUAJE EN EL PASO \\ DE LA NATURALEZA A LA CULTURA
}

\author{
José María Chamorro Calzón \\ Universidad de La Laguna
}

\section{RESUMEN}

En este artículo se intenta una reconstrucción de la influencia del lenguaje en la transformación de conocimientos y afectos primitivos, pervirtiendo en alguna forma el instinto natural; y del papel que el desarrollo del lenguaje viene jugando en dirección contraria, de la actual cultura depredadora a una futura cultura cooperativa.

PALABRAS CLAVE: naturaleza, cultura, lenguaje, barbarie, superstición, crueldad, Ilustración.

\section{THE FUNCTIONS OF LANGUAGE IN THE PASSAGE \\ FROM NATURE TO CULTURE}

\section{Abstract}

In this article we try to reconstruct the influence of language in the transformation of primitive knowledge and affects, perverting in some way the natural instinct; and the role that the development of language is playing in the opposite direction, from the current predatory culture to a future cooperative culture.

KEYWORDS: nature, culture, language, barbarism, superstition, cruelty, Illustration. 
El psiquismo de los animales sociales no los determina a la permanente prelación dentro del grupo, a la guerra de todos contra todos, sino a la cooperación y auxilio mutuo bajo el dominio del fuerte, aceptado por los demás mientras dura. La competencia obliga a demostrar superioridad frente a los retos de los aspirantes al liderazgo sin que ello origine envidias que motiven a la venganza o al asesinato. Los animales que matan para alimentarse o defenderse desconocen el sadismo y la tortura. Pueden matar fuera del grupo, pero disponen de mecanismos para resolver las disputas internas y sólo excepcionalmente acaba en muerte una pelea por el dominio. Cuando uno de los competidores se da por vencido, el vencedor se da por satisfecho. La tendencia natural del más fuerte a ejercer su dominio no tiene efectos claramente disfuncionales ni conduce a resultados patológicos, más bien es útil a la especie (los más fuertes tienen más probabilidades de propagar sus genes). El componente límbico domina la conducta de estos animales, pero no induce a la extrema violencia y crueldad que caracteriza al humano ${ }^{1}$. ¿En qué momento, y por qué, el desarrollo humano se apartó de estas pautas naturales?

\section{EL RELATO ANTROPOLÓGICO}

Los antropólogos han aportado ideas valiosas sobre este asunto a partir del estudio de culturas primitivas supervivientes. Refiriéndose a una primera fase en que la cultura incipiente aún no se ha despegado por completo de la naturaleza, Thorstein Veblen la caracteriza como cultura pacífica salvaje, en la que se lucha en grupo contra un medio no humano, la vida es sencilla y el grupo se alimenta de lo que recoge. En esta fase cuasi natural la buena voluntad y la equidad no son muy diferentes aún de su equivalente en otros animales sociales ${ }^{2}$. Marvin Harris llega por su parte a la conclusión de que originariamente las poblaciones a nivel de banda $o$ aldea, de 50 a 150 personas, se regían por el intercambio recíproco, una especie de régimen comunista. Lo que conseguía cada cual, cazando o recolectando, era de todos, pues todos sabían que ser generosos es la mejor manera de asegurarse contra el inevitable día adverso. Entre los !kung del Kalahari es ofensivo dar las gracias

${ }^{1}$ Jane Goodall ha presenciado escenas muy violentas de chimpancés atacando a miembros aislados de otro grupo. Sin embargo, esta violencia no se da dentro del grupo, entre sus miembros, salvo de forma excepcional, y en todo caso poco parecida a la humana.

${ }^{2}$ A juicio de Veblen son rasgos de esa fase el instinto de solidaridad racial-que incluye el sentido de fidelidad y equidad-y el instinto de trabajo eficaz en su expresión ingenua y no valorativa, o dicho de otra forma, el carácter pacífico, la buena voluntad, la honestidad y un interés no emulativo y no valorativo en los hombres y en las cosas. Los defectos de ese tipo de carácter serían la debilidad, la ineficacia, la falta de iniciativa y de ingenio y una amabilidad indolente que se inclina a ceder en todo frente a la fuerza o el fraude, junto a un sentido animista vívido, pero incongruente. Veblen cita como ejemplos las tribus de los andames y todas las de los Montes Nilguiri, los aínos de Yezo y tal vez algunos grupos bosquimanos y esquimales. No está seguro, sin embargo, de que estas comunidades sean casos de cultura primitiva y no casos de degeneración de una cultura más avanzada. 
cuando se recibe algo. En estos grupos los cabecillas no son jefes con autoridad para dar órdenes, más bien están sometidos a obligaciones, y para imponer su criterio han de convencer y ser ellos los primeros en el sacrificio y el trabajo ${ }^{3}$.

El intercambio recíproco pasa más tarde a ser un intercambio conocido como redistribución. En las islas Trobriand del Pacífico Sur es costumbre regalar alimentos a los jefes hereditarios, que los guardan, exhiben y redistribuyen, y ocurre lo mismo a 20000 kilómetros, entre los cherokees del sureste de los Estados Unidos, actuando los graneros de los jefes como un tesoro público al que se puede acudir en busca de auxilio. Es entonces cuando aparece un elemento nuevo: la aceptación de la jactancia como atributo del liderazgo. Los cabecillas encargados de la redistribución compiten entre sí, haciendo cada uno alardes en el intento de llegar a ser "gran hombre». Pero todavía en este estadio de desarrollo el gran hombre que ofrece los mejores banquetes se queda con las peores partes ${ }^{4}$.

Un paso más se dio, según Harris, a medida que las jefaturas expandían sus territorios, se hacían más populosas y crecían en igual proporción las reservas de alimentos y otros objetos de valor que pudieran ser redistribuidos. En estas condiciones los jefes pudieron empezar a construir el núcleo de una clase noble, respaldados por una fuerza de policía y un ejército permanente. Podían a su vez organizar prestaciones laborales a gran escala y de ahí los zigurat, túmulos, tumbas, megalitos o pirámides. Es este el momento en que los redistribuidores se compensan a sí mismos en primer lugar y en mayor medida, apropiándose de una parte desproporcionada de la riqueza social. Que unas jefaturas consiguieran llegar a constituirse como Estados y que otras se disolvieran en luchas internas dependió por una parte de que la población fuera numerosa (de 10000 a 30000 personas) y estuviera circunscrita, lo que quiere decir que, por estar rodeada de altas montańas, desiertos o selvas tropicales, no se pudiera huir más allá para evitar el poder del jefe. Dependió por otra parte de que el almacén central de redistribución estuviera lleno, pero no de tubérculos perecederos como ńames y batatas, sino de arroz, maíz, trigo y otros cereales que podían conservarse de una cosecha a otra.

Veblen considera que, además de medios de subsistencia suficientemente grandes para permitir que una parte de la comunidad quedara exenta de dedicarse al trabajo rutinario, el cambio gradual de la cultura pacífica (ese estado de cuasi naturaleza) a la denominada por él cultura bárbara exigió como condiciones hábitos de vida depredadores (guerra, caza mayor o ambas a la vez) que infligen dańos por la fuerza o mediante estratagemas, lo que a su vez requiere un progreso en la capacidad de fabricar armas. Por este camino la tendencia natural a no matar en el grupo,

${ }^{3}$ Harris cita a los esquimales, los !kung, los grupos indios brasileños mehinacus del Parque Nacional de Xingú o los semais de Malasia.

${ }^{4}$ Entre los siuais de la isla Bougainville (una de las islas Salomon) la mayor aspiración de todo joven es convertirse en mumi o gran hombre. La actitud de quedarse con las peores partes del banquete ocurre entre los Kaokas de otro grupo de las islas Salomon, actitud que los kwakiutl de la isla de Vancouver llevan según Harris a un grado ingenuamente grotesco. 
a no hacer más daño del imprescindible, pudo alterarse como consecuencia de la experiencia violenta de la caza mayor y de la lucha con otros grupos por conservar el territorio o por conquistarlo cuando no se tiene. Pues entonces se hace necesario el recurso a la hazaña violenta y, una vez que tal recurso es hábito, bien puede volverse contra el competidor dentro del grupo.

Resulta así razonable la hipótesis de que el poder para dar órdenes y ser obedecido se incubó, al igual que el poder de los hombres sobre las mujeres, en las guerras libradas por grandes hombres y jefes. Los mumis, los jefes kwakiult, los jefes trobriandeses y los jefes cherokees eran caudillos guerreros. Y las jefaturas avanzadas y los Estados incipientes documentados por la etnografía deben contarse entre las sociedades más violentas que jamás hayan existido. Las jefaturas avanzadas de la Europa céltica y prerromana, la Grecia homérica, la India védica, la China shang y la Polinesia están asociadas a destrucción de aldeas rebeldes, tortura y sacrificio de prisioneros. La Ilíada, la Odisea y la Biblia ofrecen un inventario impresionante de violencia y crueldad, cualidades que se aceptan sin escrúpulos como demostración de poder, al punto que en esos relatos se transfieren amplificadas a los dioses griegos o al dios del pueblo judío.

\section{EL ELEMENTO AUSENTE EN ESA DESCRIPCIÓN}

A explicaciones como las de Veblen y Harris les falta algo, en tanto no queda claro por qué experiencias parecidas a las que tienen otros animales sociales producen en el humano efectos tan distintos. Harris apela a la necesidad genética de amor, aprobación y apoyo emocional para explicar el deseo de ser gran hombre. A los cabecillas y mumis la sociedad no les paga con bienes materiales, sino con aprobación, admiración y respeto, esto es, con prestigio. Además de poseer talento para la organización, la oratoria y la retórica, los líderes igualitarios descuellan como personas con un enorme apetito de alabanzas. Pero podemos preguntarnos ¿por qué entre los restantes homínidos, que también tienen necesidad de amor, aprobación y apoyo emocional, no se da un proceso semejante al humano? ¿Por qué los chimpancés o gorilas que dominan en el grupo no buscan el prestigio a base de generosidad, sino que se apropian de lo que les apetece desplazando a los demás?

La violencia, la caza y la defensa a que alude Veblen se dan también en otros animales carnívoros sin que ello desate una violencia feroz entre miembros del mismo grupo, ni propicie que se aplique gran crueldad a los vencidos o a los sospechosos de conjura contra el jefe. Para Hobbes la competencia, la desconfianza y la gloria son las causas de que los hombres se ataquen unos a otros, sea para conseguir un beneficio, sea para lograr seguridad, sea para ganar reputación. Pero queda por saber de dónde surge el deseo de reputación y por qué el asesinato y la tortura llegan a ser medios para conseguir un beneficio o para lograr seguridad. Explicar nuestra especialidad respecto al mundo animal requiere añadir el efecto del lenguaje humano en la actitud elitista, que la arranca de la funcionalidad que tiene entre otros animales y la dota de nuevas propiedades afectivas. 
La cultura empieza a despegar de la naturaleza cuando unos animales sociales en los que se habían dado ciertas transformaciones biológicas fueron desarrollando una forma de comunicación mediante signos fónicos articulados. No es difícil ir inventariando las distintas situaciones que pudieron ir favoreciendo de manera natural este proceso a partir de una nueva capacidad neurofisiológica. Sobre esto me remito a LMS ${ }^{5}$. Aunque un efecto de esta emergencia evolutiva fue el progreso indudable en la comunicación, y en la capacidad para fabricar armas y para producir más de lo que se consume, hubo efectos más profundos en el cuadro de los instintos animales. El principal, del que derivan los restantes, fue un cambio radical del sistema psíquico, debido a que las imágenes mentales de las palabras son nodos neuronales cuyas relaciones forman la estructura que sistematiza los restantes contenidos mentales (percepciones, imágenes, pautas afectivas y pautas motoras), ocurriendo así que, mientras el cerebro animal está organizado en módulos independientes, ligado cada uno con un tipo de situación estimulatoria y un tipo de respuesta, las representaciones mentales de los signos hacen del cerebro humano una unidad funcional en la que cualquier elemento puede entrar en relación con cualquier otro. Esta transformación fue poniendo en juego capacidades como estas:

- Dar nombre genérico a los objetos relevantes, dar nombres propios a las personas, y nombrar las unidades de espacio y de tiempo y las relaciones entre objetos, en especial las relaciones causales.

- Verbalizar niveles de abstracción progresiva (puesto que la mente no sólo maneja percepciones para abstraer modelos, sino también modelos para abstraer modelos de modelos y así sucesivamente, y para formular razonamientos inductivos, deductivos y abductivos) $)^{6}$.

5 El estudio de cómo aprende a hablar un niño se sitúa dentro de la actividad científica (psicología evolutiva, psicolingüística, pedagogía, sociolingúística, etc.), pero cuando se trata de abordar la filogénesis del lenguaje (la forma en que fue surgiendo en grupos prehistóricos) parece que nos situamos en el espacio prohibido de las elucubraciones incomprobables. En ese espacio estaría situada la hipótesis marxista sobre la forma en que la especie humana ha ido evolucionando de la naturaleza a la cultura a través de los procesos de trabajo y lenguaje. Sin embargo, una reconstrucción lógica de los orígenes de la cultura no tiene por qué ser arbitraria. En ella juegan un papel importante conocimientos derivados del análisis de restos, del estudio de culturas primitivas, de la comparación con el comportamiento de animales sociales y de la reflexión sobre algunas condiciones lógicamente imprescindibles. Tal reconstrucción es cognitivamente fértil si nos permite ir mostrando que todo aquello de que se habla como irreductible a explicaciones científicas puede concebirse como surgiendo de una manera natural y como dotado de una estructura explicable en el lenguaje de la ciencia. Y puede llevar a conclusiones esclarecedoras acerca del carácter histórico (y por tanto mudable) de la llamada naturaleza humana, que es en realidad una multiplicidad de "naturalezas culturales humanas».

${ }^{6}$ La abducción lleva a conclusiones a partir de un conocimiento difuso, heterogéneo y generalmente implícito. Ejemplo que se encuentra en Peirce: alguien que no dispone de conocimiento específico sobre gobernadores de colonias ve en una remota colonia que unos nativos llevan a un hombre blanco en una silla gestatoria y concluye que tal hombre blanco es el gobernador. 
- Aprender por descripción, que permite adquirir conocimientos no ya sólo por familiaridad (por contacto directo con las cosas) sino además memorizando el relato que hacen otros. Y consiguientemente, la posibilidad de transmitir a las nuevas generaciones el acopio de conocimientos, valores y destrezas conseguidos por el grupo.

- Asimilar instrucciones que facilitan un aprendizaje instrumental rápido o de ensayo único y que pueden guiar una acción compleja nunca antes ensayada por el actor.

- Imaginar mundos posibles eludiendo el aquí-y-ahora, sea en la ficción, en el recuerdo, en los proyectos, sea en la consideración de alternativas hipotéticas cuando se planifica una acción. Y consiguientemente poner en marcha equivalentes imaginarios de condicionales contrafácticos: imaginar cómo sería el presente si "yo hubiera hecho x», lo que permite imaginar el futuro «si yo ahora hiciera x».

- Evaluar mediante términos que caracterizan a personas, cosas y situaciones como favorables o desfavorables, buenas o malas.

- Desarrollar un autoconcepto relacionado con las evaluaciones admitidas por el grupo.

- Experimentar nuevas formas respecto a los afectos básicos.

En conjunto estas facultades son adaptativas, y sin ellas los humanos no habríamos hecho a lo largo del tiempo nuestros progresos teóricos y prácticos. Por ejemplo, la capacidad de abstracción ligada al concepto de causa y a la creatividad verbal determina un proceso que, a través de etapas intermedias, desemboca en el conocimiento filosófico y más adelante en la ciencia, cuyo método nos permite indagar «cómo son las cosas» y decidir "cómo actuar» sobre ellas, progreso plasmado en la capacidad tecnológica actual. Y el autoconcepto ligado a elementos verbales valorativos da lugar a procesos de autocontrol que pueden contradecir las tendencias egoístas naturales y que acaban plasmados en códigos morales.

\section{EFECTOS DISFUNCIONALES DEL LENGUAJE}

Pero hay también efectos cognitivos y afectivos disfuncionales que vienen a responder a las preguntas antes formuladas. Entre los primeros la socialización y transmisión de los aprendizajes supersticiosos, la posibilidad de la mentira y el desarrollo de sistemas conceptuales sin conexión con la realidad, pero que se presentan como racionales y objetivos. Entre los segundos la transformación del deseo, la imaginación y la frustración en nuevos afectos (soberbia, rencor, resentimiento, envidia, ambición, necesidad de venganza, violencia cruel, sadismo) que no existen en estado de naturaleza. Hay otros efectos del desarrollo de la conciencia que pueden caer del lado de lo funcional o de lo disfuncional, como el aumento de la gama de sufrimientos que se sigue de que no sólo se experimenta el dolor directo, sino el añadido que se sigue de la conciencia de que se está sufriendo, de la expectativa de dolores futuros y, en definitiva, de la expectativa de la muerte. 
Se da un aprendizaje supersticioso cuando el sujeto toma una sucesión ocasional como si fuera manifestación de una ley natural. En su forma más simple, tal aprendizaje es muy frecuente en la naturaleza y ha sido fácilmente provocado en laboratorio. Si sometemos a un mono a una descarga eléctrica que suprimimos tan pronto el mono pulsa un botón desconectado de la corriente, el mono creerá erróneamente que pulsar el botón le evita la descarga eléctrica. Ocurre que mientras los animales carecen de lenguaje para transmitir sus aprendizajes supersticiosos, y por ello esos aprendizajes no pueden sobrepasar el ámbito subjetivo, en cambio el lenguaje humano vale para consolidar (objetivándolos y haciéndolos sociales y transmisibles) tanto los aprendizajes correctos, percepciones realistas, creencias verdaderas y descripciones adecuadas, como los aprendizajes supersticiosos, errores y fantasías. De esta forma las relaciones causales supersticiosas se hacen conocimiento social, se enseñan, se aprenden y se invocan.

El lenguaje permite además un tipo de superstición más elaborada, que consiste en fabricar entidades inexistentes y otorgarles poderes causales de los que cabe esperar bienes o males. Tal superstición pudo tener como origen el concepto de causa fabricado a partir de la conciencia de la propia actividad, que comprende una intención previa, una acción y unos efectos posteriores. El humano primitivo pudo generalizar este modelo llevado por una empatía extralimitada, esto es, imaginando por detrás de cada cambio inexplicable una voluntad semejante a la propia. La idea animista concibe montańas, ríos, cielo y tierra, plantas y animales como dotados de alma e intenciones. De ahí se pudo pasar a interpretar cataclismos naturales, enfermedades y muertes inesperadas, éxito y fracaso en la caza y otras cosas semejantes como decididas por seres no humanos que operaban a distancia e imperceptiblemente.

Hay que añadir el efecto de las percepciones ilusorias y los sueños. El vívido relato de quien ha visto una terrible figura en el bosque haría su efecto tanto si se debió a una percepción correcta o a una ilusoria. Y lo mismo el relato de quien habla en sueños con un difunto, refuerzo del mito, aún vigente, del alma que sobrevive al cuerpo y que puede venir a turbar a los vivos. Sujetos capaces de prever los continuos peligros, pero ignorantes de sus causas, fueron orientados por el miedo cuando lenguaje y aprendizaje supersticioso se fundieron, recibiendo así un fuerte impulso la imaginación de la que fue surgiendo una realidad, paralela a la empírica, poblada de seres fantásticos, fuerzas, espíritus, dioses.

\section{EL MIEDO CONVERTIDO EN TERROR SACRO}

Se discute si fue primero el ritual o la invención de los llamados Grandes Dioses moralizantes, esos dioses que dictan mandamientos, que todo lo ven, incluso las intenciones, y que premian y castigan en esta o en otra vida. Parece lógico que 
fueran primero los rituales 7 . Es natural que, una vez que los grupos ancestrales acabaron por dar alguna forma a lo invisible, intentaran aplacarlo de manera parecida a como se aplaca a un humano poderoso, peligroso y enfurecido: con rituales de sometimiento y de obsequio que resultarían identificatorios y tranquilizantes para los miembros del grupo. Los rituales sacros de conjuro o aplacamiento producirían en cada individuo la sensación de estarse protegiendo y, como dice Durkheim, estarían rodeados de un aura que, a la vez, espantara y atrajera, aterrorizara y encandilara. Pues al espanto y terror se une la esperanza de propiciar a una fuerza oscura y terrible y el alivio de sentirse unido al grupo ante la amenaza.

Cada cultura ha inventado espíritus benéficos, a los que encomendarse, servir e invocar en la lucha y en las desgracias, y espíritus maléficos, a los que aplacar o de los que huir, estando encomendado por lo general el control de tal mitología a algún tipo de sacerdocio, y siendo educados los niños en sus creencias y prácticas con una intensidad que viene amplificada por el rechazo comunitario a quien no las comparte.

\section{LA ESTABILIDAD DEL PENSAMIENTO SUPERSTICIOSO}

La superstición ligada al miedo es poco propensa a decaer. Si la conducta aprendida es de consecución (el animal aprende que cuando pulsa la palanca cae el grano de comida), este aprendizaje decae si más tarde, reiteradamente, a la pulsación de la palanca no sigue comida. Pero si la conducta aprendida es de evitación, el aprendizaje supersticioso es muy estable. En un ejemplo anterior, para que el comportamiento supersticioso del mono decayera tendría este que dejar de presionar el botón (y si lo hiciera comprobaría que no es necesario presionarlo). Pero no se atreverá, porque cree que recibirá una descarga.

El humano que teme un castigo terrible difícilmente se atreverá a ver qué pasa si abandona su creencia. Si se atreviera, su propio miedo sería ya la primera fase del castigo y cualquier daño que pudiera ocurrirle después sería achacado a su acción impía y no a la verdadera causa ${ }^{8}$. El terror que hace casi invulnerable este tipo de

$7 \mathrm{H}$. Whitehouse defiende que no fueron los dioses moralizantes, sino los rituales religiosos, los que ayudaron a crear una identidad colectiva y un sentimiento de pertenencia, al actuar como un pegamento social y ayudar a que la gente de estas sociedades complejas cooperase. «En casi cualquier región del mundo de la que tenemos datos -dice-, los dioses moralizantes tendieron a seguir, no a preceder, a los crecimientos de la complejidad social», lo que sugiere que las prácticas rituales fueron más importantes que el contenido particular de las creencias religiosas. Luego esos rituales facilitarían la estandarización de las tradiciones religiosas a través de grandes poblaciones.

${ }^{8}$ Habermas postula un concepto de lo sacro previo al lenguaje, pero lo hace por necesidades de dualista, no por razones convincentes. Ni el aprendizaje supersticioso ni el terror por sí solos, sin lenguaje, pueden generar una idea de lo sacro. Afirmar que los rituales sacros fueron el origen del lenguaje sólo se le puede ocurrir a quien quiere encontrar una raíz prelingüística a la moral con la esperanza de que, por ser preligüística y no encontrarse en otros animales sin lenguaje, sea una espe- 
aprendizaje acompaña al hombre desde su origen hasta que va consiguiendo convertir el aspecto mágico de la causalidad primitiva en leyes de la naturaleza. Pero respecto a la mayoría de la población la alianza entre ignorancia y miedo persiste aún en nuestros días, haciendo que mil supersticiones (entre ellas las religiosas) sean tan inseparables de muchas personas como su misma piel y no haya argumento racional que las elimine.

\section{LA CAPACIDAD DE MENTIR}

Además de la socialización del aprendizaje supersticioso, otra de las consecuencias disfuncionales del lenguaje es la posibilidad de la mentira, junto con habilidades laterales que permiten el establecimiento de la mentira como verdad colectiva ${ }^{9}$. De cómo el disimulo y la simulación intencional funcionan en algunas especies animales es ejemplo el chimpancé que yendo en grupo ve unos plátanos junto a la senda y disimula para volver más tarde y evitarse el reparto con los otros. Pero el animal no pasa de ahí. De una forma muy natural el niño aprende estrategias de mentira, de fingimiento o de ocultación antes de aprender a hablar. El nińo no sólo llora cuando algo le duele o necesita ayuda, sino que, en la medida en que su llanto es reforzado, aprende en seguida a controlar la conducta de los adultos mediante el llanto. De esta forma el llanto es a veces síntoma de desarreglos que requieren ayuda, pero es a veces un recurso de control. En estos casos implica un fingimiento. Una vez que sabe hablar, el niño aprende a negar su acción para eludir el castigo, y aprende que gana elogios si finge una hazaña.

La mentira, el fingimiento o la ocultación como recurso espontáneo para defenderse de una acusación, conseguir alguna ventaja, hacer daño a otro o atraer la atención ajena debieron surgir en las primeras generaciones de humanos tan espontáneamente como en el niño. Luego la facultad de mentir, acrecentada, se iría convirtiendo en una estrategia utilizada reflexivamente. Es entonces natural que la veracidad se estableciera como conducta obligada cuando resultaron insoportables la inquietud y desconfianza producidas por el uso impropio de la palabra. Pero, puesto que la mentira sólo es tratada como tal cuando se descubre, el campo quedó libre a los hábiles fingidores de la actitud con que se habla cuando no se está mintiendo, algo facilitado por los muchos crédulos, incapaces de descubrir la mentira allí donde se produce, incluso aunque sea obvia. Especialmente cuando la mentira se apoya en un aprendizaje supersticioso que nadie se atreve a someter a prueba. $\mathrm{O}$ cuando, en alguna medida, conviene a quien la cree. Quedó, pues, un amplio campo de acción

cie de alma insuflada por la divinidad. Lo sensato es pensar que primero fue el lenguaje y luego la fabricación supersticiosa de lo sacro.

9 La mentira es una característica tan exclusiva del lenguaje humano que ha sido definida como aquel medio de comunicación que sirve para mentir. 
a los capaces de engañar con eficacia y también a los hábiles en presentar su mentira como remedio al miedo colectivo.

\section{JEFATURA, PROPIEDAD Y LENGUAJE}

Dejemos hasta más adelante estas disfunciones del lenguaje y pasemos a examinar el surgimiento de los conceptos de jefatura y propiedad, de los que el animal no dispone. En el mundo natural la superioridad demostrada por el macho dominante no va unida a la idea de preeminencia, ni en los dominados a la idea de inferioridad, y por ello no ocasiona envidias ni venganzas. El elitismo animal no está ligado a la idea «yo» y a las ideas derivadas «jefe»o «súbdito». El paso de macho dominante a jefe requiere desarrollo del lenguaje. Es necesario que antes se haya dado nombre, por rudimentario que sea, al valor y a la cobardía, a la fortaleza y a la debilidad, a la hazaña que se canta y a la habilidad verbal que se festeja. Sólo entonces se puede pensar en el "gran hombre» que reúne valor, fortaleza y retórica. Sólo entonces puede aparecer el deseo de ser "gran hombre».

Una vez que la dominación natural se institucionalizó como jefatura no se trató ya del poderío ocasional del más fuerte, que surge en momentos eventuales como un mero hecho, sino de la superioridad permanente, garantizada por los significados compartidos. A su vez, no hay algo que pueda interpretarse como fundamento biológico de la propiedad, ni siquiera en los animales territoriales, cuyo comportamiento se limita a la posesión. El animal dominante delimita y defiende su territorio, trata de impedir que otro cace donde caza él y defiende la comida que tiene entre garras o dientes, pero ajeno a cualquier idea o representación de que «él» sea propietario de esa comida o de ese territorio. El animal no puede distinguir entre posesión y propiedad, no puede pensarse a sí mismo como propietario de algo que no esté poseyendo o esté a su alcance en el acto. $Y$ es que, mientras la posesión consiste en una conexión directa entre poseedor y cosa poseída, la propiedad va más allá, establece una conexión que funciona en ausencia y que por ello no es natural, sino semiótica. Los miembros del grupo deben respetar el derecho de un propietario ausente, cuya relación con el objeto sólo funciona en los significados culturales compartidos. La posesión implica uso y disfrute de la cosa, la propiedad no necesariamente. Alguien puede ser propietario de unos terrenos que nunca ha visto y que sólo le ocasionan costes.

Rousseau pensaba que la maldad y la corrupción de la humanidad civilizada habían comenzado cuando alguien valló un trozo de terreno y dijo "esto es mío», $y$ tal idea encierra en su simplicidad mucha verdad, en el sentido de que casi todas las instituciones humanas (sociales, religiosas, políticas) giran en torno al derecho de propiedad, del que derivan casi todos los males sociales que percibimos. Pero es evidente que no bastaría con que cualquiera dijera «esto es mío». Fue además necesario que el grupo lo aceptara, y ello implica un proceso ideológico en el que el concepto de propiedad debió ir unido al de jefatura. No es cualquiera el que puede decir «esto es mío» seguro de que se va a respetar su voluntad. La posesión comunal de los bienes del grupo pasó a ser propiedad cuando se estableció como derecho del 
jefe a acumular riqueza social en detrimento de la mayoría. Para que la propiedad y la preeminencia se hagan instituciones permanentes, garantizadas por los significados compartidos en la tribu, es necesaria una definición de títulos, derechos y obligaciones y una forma de percepción social (y de autopercepción). De manera que el paso de predominio de facto a predominio de iure debió tomar la forma lingüística de un reconocimiento (reconocimiento del poder del más fuerte en la lucha, convertido ahora en jefe, y reconocimiento de la propiedad del jefe, que hace suyos los excedentes) y de una norma («obedecerás al jefe y no robarás lo que es suyo»). Al dar nombre a estas cualidades, relaciones y normas no sólo se toma conciencia de ellas, además se las convierte en objetos relacionables con todas las cosas restantes que han recibido nombre.

En una situación en que la fuerza es el recurso básico, tanto para la caza como para la defensa, el hombre más fuerte domina a los hombres restantes y los hombres dominan a las mujeres. Para este dominio valen las manos y las armas. El fuerte puede sujetar, golpear y hacer tanto daño que su presa sólo puede salvarse aceptando el dominio. El hombre débil y la mujer estarán a salvo si son defendidos por el hombre fuerte, al que deben someterse a cambio de la seguridad frente a otros. Debió ser muy natural en esa situación que el más fuerte se creyera dueño de los bienes apetecibles, entre ellos las mujeres. Puesto que la propiedad es un asunto social, en muchos tramos de la historia las mujeres han sido propiedad de los hombres, los esclavos propiedad de sus dueños.

\section{NUEVOS AFECTOS}

Que entre animales sociales el dominante no sea asesinado podría explicarse porque con su dotación natural el menos fuerte no puede matar al más fuerte ni siquiera atacándolo por sorpresa. Pero un chimpancé podría coger una piedra y atacar con ella al dominante que duerme. Si no lo hace es porque no dispone de un lenguaje de agravios, causas y expectativas, ni de nombres propios, ni de términos generales y términos como «yo», «mismo que», etc. De manera que, cuando es dominado, no puede concebirse como "yo» agraviado, ni puede recordar al fuerte como un sujeto permanente que es causa de su dolor, ni puede siquiera concebir que el animal que aparece en dos situaciones radicalmente distintas, aquella en que le domina y aquella en que podría ser víctima de su venganza, sea "el mismo", ni puede imaginar ventajas derivables de la desaparición del otro. Sin un lenguaje como el humano, los estímulos dejan al organismo preso de la situación en que ocurren ${ }^{10}$. Y ni la vanidad ni la ambición ni la admiración ni la envidia son sentimientos determi-

10 Es impresionante la escena filmada en que una chimpancé y su hija arrebatan la cría a otra, la matan y la devoran. A continuación, la hembra adulta que ha matado a la cría abraza a la madre, que por su parte se deja tratar amistosamente, pese a que ha presenciado lo ocurrido. A falta de lenguaje no puede hacerse una idea discursiva y evaluativa de lo que ha presenciado. 
nantes en la relación del dominante con los sometidos y de estos con aquel. Incluso cuando el fuerte acaba debilitándose y es desplazado por otro más fuerte, no tiene en su mente ideas sobre sí mismo que le dificulten aceptar su ocaso.

En cambio, el lenguaje debió determinar que el éxito social ajeno y el fracaso propio generaran resentimiento. Pues por diferencia con el animal, el aspirante a la jefatura tenía ya lenguaje para darse nombre a sí mismo (para saberse, por tanto, como sujeto) y para dar nombre al dominante y concebirlo como causa de su frustración. Es la capacidad del lenguaje para el razonamiento la que hizo surgir la envidia (lo que "yo» quiero y merezco lo tiene «él» y no lo tengo yo porque lo tiene él). Y la capacidad del lenguaje para crear situaciones virtuales hizo aparecer la ambición y la venganza. No es ya que alguien desee algo presente y sea desplazado por el más fuerte cuando intenta apresarlo, sino que puede imaginarse poseyendo más adelante lo que hoy no puede conseguir, y puede imaginar estrategias para conseguir más adelante lo que desea. El lenguaje que hace surgir la envidia y el deseo facilita la maquinación para realizarlo. Dada la estructura mental organizada por el lenguaje, fue inevitable que, tan pronto se sintiera impune, el ambicioso o el resentido acabara realizando la única acción efectiva, el asesinato. Pues para vengarse del poderoso y eliminarlo de la competencia no tiene el dominado otra opción que matarlo. Si simplemente lo agrede, no ha hecho otra cosa que enfurecerlo y exponerse a su castigo. De forma que cuando el aspirante pudo completar sus fuerzas con un arma (condición necesaria para matar sin lucha), mató por sorpresa al que frustraba su deseo. El asesinato por envidia o ambición es un episodio primigenio que aparece mencionado en los mitos que explican los orígenes en distintas culturas ${ }^{11}$. Es razonable suponer que el sucesivo asesinato de los dominantes por los aspirantes tuvo que convertirse en obstáculo a la adaptación del grupo. Los mejores guerreros iban cayendo y el grupo se hacía vulnerable frente a grupos enemigos. El miedo ante la propia debilidad se transmitiría al hecho que la originaba y todos coincidirían en los gestos de horror cada vez que se consumaba un nuevo asesinato.

${ }^{11}$ Baste citar las aventuras mitológicas de Set y Osiris, y de Urano, Cronos y Zeus. En el relato bíblico podemos interpretar que el demonio interno (el lenguaje) sugirió a Adán matar al jefe para quedarse con el paraíso. Comer la manzana sería una metáfora de matar al jefe (en el relato bíblico a dios) para ocupar su puesto. Lo que Adán tenía prohibido era maniobrar para dejar de ser súbdito. Dios está concebido en ese relato como un jefe que tiene miedo a ser derrocado y que por eso es cruel en el castigo. Por su parte Caín mató a Abel porque Abel era grato a los ojos de dios (o a los ojos de su hermana), y Caín no lo conseguía por más que se esforzaba. La referencia a la complacencia divina o a la posesión de la hermana puede entenderse también como una metáfora. Caín representa al aspirante envidioso del éxito social que ha alcanzado otro y que puede ser suyo si el otro muere. Las luchas a muerte por la primogenitura están patentes en numerosas historias bíblicas (Esaú y Jacob, Ruben y José, etc.). El asesinato de reyes o aspirantes ha estado a la orden del día (la historia de Cleopatra es una de las muchas sagas de asesinatos en serie con el poder como motivo), lo mismo que las incontables masacres, torturas y genocidios por prevención o venganza. 


\section{EL REMEDIO PREFERIBLE (Y TODAVÍA IRREALIZABLE)}

La salida de esta situación autodestructiva tiene teóricamente dos caminos. Uno, que es el que se ha seguido, consiste en mantener el elitismo y conservar la cohesión y la fortaleza frente al exterior, inicialmente fabricando una norma del tipo «no matarás dentro del grupo» (y menos, claro está, a tu jefe) que viene a complementar la norma previa «obedecerás al jefe y no robarás lo que es suyo». La deficiencia de esta solución viene de que la prohibición y el castigo de la violencia no eliminan su causa. En la medida en que esa prohibición tenga éxito, evita el efecto criminal del resentimiento o de la ambición, pero no el resentimiento o la ambición; y además no tiene éxito completo en muchos casos: puesto que esa prohibición sólo interesa realmente al que ejerce dominio, no al que lo padece, este sólo la aceptará por miedo a la represalia, pero en principio tenderá a eludirla en las situaciones en que calcule (a veces con acierto, a veces con error) que la transgresión puede resultar impune. Y en esa transgresión se arriesgará temerariamente, empujado por el deseo de preeminencia ante las hembras (e instrumentalmente de riqueza y poder).

Ello hizo que frente al resentimiento y ambición del dominado estallara la soberbia del dominante amenazado. Pues la soberbia es otro de los sentimientos que emergen de la unión de elitismo y lenguaje. En seguida la tortura surge al dictado de la ira inteligente. El lenguaje permite que el poderoso se pregunte qué es lo que puede infligir un dolor más grande a quien ha osado disputarle el poder o agredirle a traición, dolor que sirve de venganza y también de escarmiento en cabeza ajena. El lenguaje permite imaginar la tortura y convertirla en conducta instrumental, sea como prevención, como castigo o como forma de obtener confesiones. Y así, cuando los nuevos sentimientos egocéntricos se hacen dominantes, se llega a la ejecución de feroces represalias, incluso a la demostración de poder decretando torturas o muertes sin motivo.

Hay en pura lógica otra alternativa a la violencia dentro del grupo: suprimir su causa optando por un orden igualitario en el que poder y riqueza se repartan de manera que ninguna persona o grupo pueda lograr una posición privilegiada. Pues el grupo también sobreviviría, aunque con estructura diferente, si en vez de quedar prohibida la violencia provocada por el elitismo se estableciera un pacto de no ejercer dominio y de repartir equitativamente los bienes. Eliminado el elitismo, y por tanto la motivación básica para la violencia criminal, todo serían ventajas colectivas. El capaz de obtener ventajas elitistas estaría sacrificándolas, pero a cambio de otras superiores. En una sociedad igualitaria habrían desaparecido muchas causas evitables del miedo, el permanente cuidado a que obliga el ejercicio del poder, la desconfianza al otro y muchas de las barreras a los placeres de la interacción amistosa.

La opción entre los dos remedios posibles, el elitista y el igualitario, es la decisión política básica desde el punto de vista lógico, y es por ello interesante evaluar la estructura social por relación con esas dos formas, sin que en este punto importe si se han dado o no en la historia sociedades igualitarias más complejas que las de cazadores-recolectores. Se hayan dado o no, y se puedan dar en el futuro o no, es ciertamente un tipo de organización social posible y ha estado muchas veces en el deseo o aspiración de filósofos y reformadores sociales. Es por tanto relevante expli- 
car por qué en el presente no se da una organización igualitaria, y cómo se justifica, frente a su posibilidad, la organización elitista.

Lo que parece cierto es que inicialmente la opción entre estos tipos de sociedad no ha estado disponible. Hobbes creyó que la causa de la guerra de todos contra todos se debió a la igualdad natural de los hombres, y que de esa guerra se salió mediante un pacto entre iguales que funda el Estado. Pero hay que contar, frente a Hobbes, con la situación de desigualdad originaria, con la diferencia de fuerza que se da inicialmente entre padres adultos e hijos pequeños, entre machos y hembras, y entre machos fuertes y débiles, precisamente cuando es la fuerza física el recurso que dirime las disputas y otorga el poder. Entonces, si nos remontamos a los orígenes, debemos hablar de competencia en situación de desigualdad (la desconfianza y la gloria de que habló Hobbes como causas de la discordia fueron sin duda efecto de la desigualdad).

Así que la primera gran decisión política nunca fue, como Hobbes supone, un arreglo entre iguales, sino entre fuertes y débiles, y no había suficiente conocimiento acumulado como para que los fuertes hicieran los complejos cálculos que pueden motivar al sacrificio de la apetencia primaria. Tal conocimiento ni siquiera ahora, según se percibe, está a disposición de la mayoría. Así que hubo de ocurrir necesariamente que, con una psicología poco trabajada, no cargaran los fuertes con la renuncia, sino que hicieran cargar a los débiles con la sumisión.

\section{ESFUERZOS LEGITIMARIOS}

Otro aspecto interesante de este proceso es que el lenguaje, que lleva inevitablemente a dar nombre a los distintos papeles y más tarde a institucionalizarlos, genera antes o después la obligación de aportar razones justificativas del reparto desigual de bienes y de poder. El elitismo animal no necesita justificación. El fuerte domina y no está en su mundo la pauta de dar razones, pero el humano dominante se ve obligado a explicar por qué los demás deben respetar que él se lleve la mejor parte siendo así que es verbalizable otro tipo de reparto, es decir, se ve obligado a explicar por qué los demás deben obedecer y renunciar a satisfacer las demandas de la envidia, la ambición y la venganza. Una vez que son imaginables, al hilo de las palabras, situaciones que contrastan con la real, es efecto de la racionalidad incipiente la necesidad de legitimación, que consiste en responder al "por qué esto y no aquello» con alguna fórmula convincente. De ahí que, una vez que la dominación natural y el disfrute desigual de bienes se institucionalizaron como jefatura y propiedad, el lenguaje tuvo que desarrollar un léxico de motivos y justificaciones, necesidad que llega al punto de que, si quisiéramos encontrar una ley histórica muy general, deberíamos centrar la atención en los numerosos efectos de la relación entre la persistencia del elitismo y la necesidad cultural de legitimarlo, cuya quiebra favorece insurrecciones y represiones.

El problema es que la justificación de la prerrogativa del dominante ha de tener carácter nietzscheano si es sincera: «Hago lo que quiero y tomo lo que quiero porque soy más fuerte. Nadie es capaz de impedírmelo y jay de quien se atreva!». 
Ahora bien, si se toma este camino veraz no se puede evitar que de la misma forma legitime su crimen quien asesina al jefe, el cual puede decir: «He matado al jefe porque he tenido fuerza para hacerlo». De ahí que las prerrogativas del dominante, y las normas derivadas, requieran ser legitimadas con algún tipo de argumento que no pueda hacer suyo el dominado. Hay un argumento pragmático que habla de la necesidad de un líder a salvo de peligros y acatado por todos, argumento condicional que viene a decir: «Si quieres que el grupo sobreviva, y por tanto tú mismo, debes acatar al jefe y no intentar nada contra él». Pero este argumento no vale frente al aspirante que lo acepta, pero creyendo sin embargo que el jefe debe ser él.

Además, tal norma tiene naturaleza instrumental (en la medida en que es condición para la supervivencia del grupo) y, por ello, aunque inicialmente estén motivados a seguir la norma cuantos acaban de vivir el hecho originario que puso al grupo en peligro (el asesinato de los sucesivos jefes a manos de los sucesivos aspirantes), tal norma perderá efectividad si se transmite a las generaciones siguientes con su carácter instrumental, y por tanto hipotético. Pues, como ha sido puesto de manifiesto por algunos teóricos ${ }^{12}$, el interés individual que hace asumible esa norma es sólo indirecto, depende de la creencia de que la suerte futura del grupo está condicionada a la conducta prescrita. Pero el funcionamiento de esta norma es paradójico: su relación con el hecho catastrófico que la hizo nacer se irá oscureciendo en la medida en que sea cumplida (puesto que ese cumplimiento conseguirá, precisamente, que el hecho originario no se repita); de forma que si se transmite con su carácter de norma técnica, las nuevas generaciones, que no han vivido el hecho originario, tienen que cumplirla por una relación sólo indirecta con el beneficio individual, y esa relación será continuamente cuestionada por inexperiencia del hecho en que se funda. De ahí que la norma fundacional de la jefatura requiera ser legitimada como norma incondicional.

\section{LA LEGITIMACIÓN SACRA}

Así es como entra en escena la legitimación sacra en unas u otras formas.

Una elemental es la creencia polinesia de que el mana es una fuerza o poder vinculado a los altos jefes, cuyas propiedades y cuerpos son tabú y nadie puede tocarlos sin caer fulminado.

Otra más compleja, presente en las jefaturas avanzadas y los primeros Estados, es la creencia en entidades que superan al humano, desde las puramente impersonales a los dioses llamados moralizantes ${ }^{13}$.

12 Por ejemplo, Berger y Luhmann, pioneros de la sociología del conocimiento.

13 El primer dios moralizante que se conoce es Ra, dios del sol, relacionado con el enterramiento ritual de las élites. Era representado con cuerpo de hombre y cabeza de halcón por los egipcios de la Segunda Dinastía y su manera de juzgar era según el código maat, que representaba «lo que es correcto", como proteger a los débiles y no robar. Algo después surge Shamash durante la dinas- 
La historia nos ofrece un amplio muestrario: los dioses egipcios representados con cabeza animal (halcón, carnero, cocodrilo, chacal, leona, ibis, escarabajo o lebrel), los dioses de Mesopotamia, Grecia y Roma con figuras y pasiones humanas, pero inmortales y poderosos, los toltecas y aztecas que exigían sacrificios humanos, o el dios único de judíos, cristianos y musulmanes. Fabricados estos dioses, un tipo de legitimación sacra de las prerrogativas regias ha sido, como indica Harris, la reivindicación de descendencia divina: los jefes supremos de Hawái, los emperadores del antiguo Perú, de China y Japón y los faraones de Egipto se decían descendientes del sol. Una forma más elaborada es el mandato divino que da valor incondicional a la norma que preserva jefatura y propiedad. Pues una vez que el grupo ha inventado una rudimentaria teología o superstición ligada al terror con que se percibe el mal inexplicable, qué más natural que legitimar las normas básicas del elitismo (el respeto a la propiedad privada y a la vida de los propietarios) achacándolas a la voluntad de una entidad capaz de ayudar y de destruir.

Discuten los etnógrafos si la invención de los dioses moralizantes fue un prerrequisito de la evolución de la complejidad social, o si más bien fue un efecto de ella. La visión más aceptada es que las antiguas sociedades de cazadores-recolectores vivían en grupos tan reducidos que casi cualquier comportamiento inmoral era detectado en seguida por todos. En cambio, en las grandes sociedades el comportamiento inmoral puede pasar inadvertido con grave peligro para la estructura social, y de ahí la necesidad de los grandes dioses que lo ven todo y que castigan el pecado. El defecto de ambas posiciones es que consideran el tamaño y la complejidad de las sociedades, pero no enfatizan el dato básico ${ }^{14}$. Y es que la necesidad de legitimaciones sacras de jefes y normas provino no tanto del tamaño o la complejidad de la sociedad, ni del hecho de que en un vasto imperio tuvieran que colaborar personas de distintas lenguas que no se conocían, ni tampoco de que en una gran sociedad se pueda mantener en secreto la mala conducta, sino del hecho de que en esas grandes sociedades había élites y había masas explotadas. En una sociedad igualitaria, no importa cuán extensa y compleja, no resultará imprescindible un dios que prohíba matar y robar. Sin embargo, el robo y el homicidio son prohibiciones comunes a todas las religiones cuyo dios dicta normas de comportamiento.

tía Akkad en la actual Irán, también dios del sol, que todo lo ve y que castiga a los «injustos» (aquellos que mienten o roban).

${ }^{14}$ Así, por ejemplo, la investigación dirigida por $\mathrm{H}$. Whitehouse y publicada en Nature, que compara 414 sociedades de 30 regiones en un periodo de 10000 años, desde la Antigüedad hasta la Revolución Industrial, clasificadas de acuerdo con 51 medidas de complejidad social: desde cuántas personas la conformaban y si el gobierno tenía un liderazgo jerárquico hasta qué sistemas de información existían. A su vez, han buscado determinar si cada sociedad creía en un dios o dioses moralizantes o en una fuerza sobrenatural vinculada a los valores de la lealtad y la honestidad, y con qué frecuencia y estandarización exhibían rituales religiosos. 
El débil astuto comprendió en seguida que se hacía insustituible si podía poner la magia o la teología de la tribu al servicio del jefe. El incapaz de imponerse por la fortaleza física puede sobrevivir y prosperar poniendo en juego su habilidad con las palabras si es capaz de usarlas para crear y para convencer, y por eso la alianza del jefe con el hechicero (o de la fuerza con la astucia teológica, o del trono con el altar) es tan antigua como la necesidad de legitimación del elitismo. Y como es ventajoso para los beneficiarios que los mitos legitimatorios sean siempre afirmados por personas que gozan de suficiente credibilidad, y con los gestos, entonaciones y actitudes de la máxima dignidad (ritual, académica, moral), todo ha de establecerse para que quienes dicen las más grandes mentiras ideológicas pasen por personas serias y fiables y muchos que dicen la verdad no consigan crédito y sean perseguidos por sacrílegos. La credibilidad privada suele ser personal, ganada a lo largo de comportamientos veraces, pero la pública es institucional, ligada a cargos o profesiones y, por ello, paradójicamente, las personas que gozan de mayor credibilidad social son las encargadas de producir y expandir las mentiras más rentables, aquellas con que se fabrica la opinión de las masas sobre los derechos de la élite.

La alianza del trono y el altar se percibe en todas las sociedades conocidas, incluidas las más primitivas. En las islas Hawái, por ejemplo, el rey mantenía junto al séquito de guerreros un séquito de sacerdotes. Entre nosotros la alianza de una religión emergente con el poder civil tuvo lugar con el Edicto de Tesalónica del 380 , por el que el emperador Teodosio convertía al cristianismo en religión oficial del imperio, y de esa alianza legitimadora son ejemplos paradigmáticos la coronación de Carlomagno por el papa León III, de Otón I por Juan XII, y de sus herederos en una serie sucesiva en que la intervención del papa era indispensable para otorgar la condición de emperador. Tal imperio se presentaba como vocación universal de gobernar y evangelizar a los pueblos. Incluso la propiedad sobre los territorios descubiertos y por descubrir fue repartida entre España y Portugal por una bula del papa Alejandro VI, quien, como intérprete de la voluntad divina, legitimaba tal propiedad. Ejemplos más recientes los vemos en el apoyo legitimario que la iglesia católica ha prestado a dictadores sangrientos que, a cambio, la beneficiaron. Franco se titulaba caudillo de España por la gracia de dios y la iglesia católica le concedió el honor de entrar bajo palio en las catedrales.

Es asunto interesante si el inventor de las mentiras puede llegar a creer en ellas. Es posible que sí, pero no es relevante en este relato. Los romanos, uno de los pocos pueblos que no tuvieron una profesión exclusivamente sacerdotal, tenían cargos religiosos ocupados por destacadas figuras de la vida pública. De esta forma, en palabras de Cicerón, los ciudadanos más distinguidos salvaguardaban la religión mediante la buena administración del Estado y salvaguardaban el Estado mediante el sabio control de la religión. El mismo Cicerón, que no creía en los augurios, estaba orgulloso de haber sido elegido augur. Y en general, el culto público a los dioses se mantenía por patricios escépticos que fingían de cara al pueblo. De manera que lo relevante es que poder político y poder religioso, no importa bajo qué formas cam- 
biantes, han mantenido una continua alianza en beneficio mutuo, siendo efecto de tal alianza la legitimación de sistemas políticos explotadores ${ }^{15}$.

La legitimación sacra se ha acompañado de otras complementarias, especialmente la patriótica. Aprovechando el encariñamiento de cada cual con la tierra en que ha crecido, la minoría dominante ha solido identificar sus propios intereses con los de toda la población exaltando a la tribu o nación y su territorio, fingiendo que el grupo y su territorio son una entidad que acoge a todos sus miembros como hijos (la madre patria), a la que hay que servir y defender, para conseguir así que los perjudicados por los intereses de la minoría defiendan esos intereses arriesgando o entregando la propia vida. De esta forma se ofrece un «nosotros» en cuyo seno se disuelven ideológicamente los intereses encontrados de unos y otros, y los miembros de las masas se consideran hermanados con los miembros de la élite. Para esta transmutación han contado los poderosos con otros tipos de sacerdocio, reclutados en el campo de la literatura y la filosofía. Una parte del ritual legitimatorio, sea el que sea, consiste en el llamado por Veblen consumo conspicuo, centrado en objetos suntuarios (vestimenta, adornos, vivienda) que vienen a demostrar que el jefe no es una persona como las demás. Y en la magnificencia de los templos dedicados a honrar a los dioses.

\section{DISTINTOS TIPOS DE SOCIEDAD ELITISTA}

En este marco muy general es fácilmente integrable la teoría marxista sobre los distintos modos de producción entendidos como diferentes formas de sociedad elitista que van emergiendo conforme aquí o allí se produce un cambio en la forma de adaptación económica del hombre a su medio. En cualquiera de los sistemas elitistas históricos interactúan individuos pertenecientes a diferentes clases sociales, estableciéndose entre ellas, como fundamento causal de numerosas actividades e instituciones, relaciones de parasitismo. Los individuos y grupos de la élite (para los que los restantes miembros de la sociedad son simple entorno) imponen constricciones fundamentales y de ahí que numerosas metas de actores (individuales y colectivos) estén concertadas de tal forma que producen como resultado la persistencia de ese orden social.

${ }^{15}$ La idea de la legitimidad del poder absoluto y arbitrario ha estado asimilada hasta tal punto por el pueblo que los relatos o cuentos de esa arbitrariedad cruel (por ejemplo, que un rey mande decapitar a sus adivinos porque no han sabido explicarle un sueño, o que un sultán se despose cada noche con una virgen y la mande ejecutar al día siguiente) han sido aceptados con naturalidad y como si no perjudicaran la imagen del poderoso, sino que lo hicieran más admirable. Scheherezade se casa con el sultán cuando este ya ha mandado ejecutar a 3000 precedentes y se entiende que el sultán y ella son felices y que ella ha tenido buena suerte al casarse con hombre tan poderoso. 
Desde este punto de vista interesa destacar que, frente a lo que han afirmado G.H. Mead, T. Parsons o J. Habermas, el mecanismo de la socialización no consiste en que todos los miembros de la sociedad interiorizan los valores de la cultura compartida, sino más bien en que los miembros de cada clase interiorizan los conocimientos, valores y pautas de su correspondiente subcultura, pero en un ambiente en el que la clase dominante impone, claro está, las creencias legítimas, los valores aceptables y el sentido de la excelencia ${ }^{16}$.

Los aspectos culturales no forman, por tanto, un solo «mundo de la vida» compartido, sino tantas concepciones del mundo como clases relevantes respecto a la reproducción y el cambio del orden social. Y en este punto hay que consignar que no ocurre sólo que cada grupo se socializa en una subcultura, sociolecto o vernacular diferente, sino que la socialización de los grupos dominados es interferida por los procesos de adoctrinamiento que los grupos dominantes inducen a través del control de la comunicación prestigiosa, sea mediante el arte (pintura, escultura, arquitectura), los restantes signos del poder y los púlpitos, sea además, en su caso, mediante las escuelas y los medios de comunicación. La capacidad de convicción de la ideología legitimatoria llega al punto de que incluso el paria de India llega a creer que nació paria y que puede reencarnarse en mejor forma si acepta su condición de paria y se porta según ella. Sigue siendo algo muy natural admirar y envidiar la fortaleza y el poder con que alguien se impone a los demás (por ejemplo en las finanzas, en la guerra, en el deporte) y valen para ello los diferentes signos de su superioridad. En esta complejidad hay que buscar el sentido de las determinaciones estructurales actuando sobre determinaciones individuales. La capacidad de actuación y de relación social de cada individuo viene en gran medida predeterminada por la posición que ocupa en la estructura social, y lo mismo su influencia en los procesos que afectan a esa estructura (a su mantenimiento y cambio).

\section{LA REPRESIÓN COMO COMPLEMENTO DE LA LEGITIMACIÓN}

Con frecuencia el deseo de justicia y el conocimiento que desenmascara la impostura pueden más que el miedo a incumplir una ley deslegitimada, y por ello surgen con más o menos profusión personas y grupos rebeldes. De ahí que los mecanismos de adoctrinamiento hayan de completarse con los de control cada vez que el adoctrinamiento no consigue presentar como relaciones de cooperación y complementariedad las relaciones de dominio y parasitismo, o como natural la situación

16 Puesto que la teoría sociológica conservadora oculta la realidad de clases e ideologías bajo la ilusión de una cultura compartida o de un trasfondo común de significados, habría que considerar a las teorías weberiana, parsonsiana y habermasiana como formando parte no tanto de la ciencia social como del discurso más elevado de un complejo proceso de adoctrinamiento. 
de inferioridad social. Es entonces preciso reprimir (excluyendo, demonizando, torturando, asesinando) el libre desarrollo de la disidencia y la rebeldía. Es patente que el único acuerdo posible dentro de las sociedades elitistas ha venido consistiendo en que los dominados acaten la norma y renuncien a la violencia, y que el dominante les ofrezca protección a cambio de sumisión, protección que muchas veces se ha limitado a mantener en suspenso la amenaza de represalias.

\section{SEGUIMOS EN LA CULTURA BÁRBARA}

Según lo hasta aquí expuesto, no son nuestros genes los que han dado lugar a rasgos psíquicos de gran malignidad, sino la mezcla del elitismo animal con el lenguaje, que es inicialmente patógena y que ha ido tiñendo de dolor y sangre innumerables episodios de la historia humana en la fase de cultura bárbara en la que aún persistimos. Puede parecer una boutade decir que los humanos actuales, incluyendo los occidentales blancos, aún no hemos salido de esa primera fase de cultura bárbara. Pero si la caracterizamos por la institucionalización del elitismo (la explotación de unos por otros, y la consiguiente división en clases y etnias dominantes y dominadas), por las nuevas emociones que de ello se derivan y que inspiran actividades tan características como el asesinato, la tortura y el genocidio, por la mentira con que hay que legitimar la explotación de la mayoría por la minoría y por el predominio de la ignorancia supersticiosa, que facilita la mentira y completa su función, entonces, pienso, tendremos que aceptar que todavía nos mantenemos de lleno en la barbarie.

A nuestro alrededor se hace evidente que las poblaciones están caracterizadas por la ignorancia, dominadas por supersticiones religiosas y otros mitos y magias, a cada paso amenazadas por la violencia, sosteniendo sistemas sociales de llamativas injusticias, y controladas por la mentira legitimatoria puesta en juego por una codicia cínica. De todo ello son prueba las espantosas muestras del siglo xx, y aunque parezca que se ha reducido la violencia homicida en el seno de ciertas sociedades, el interminable reguero de matanzas, asesinatos, torturas y guerras que desembocan en un mar de sangre persiste en nuestros días si consideramos el mundo en general. Y hay que aceptar que en muchos casos se trata de una violencia promovida en su propio beneficio por las sociedades llamadas democráticas, en cada momento silenciado, si no justificado o legitimado con diversos discursos. Si ańadimos la violencia que aplican numerosos individuos contra otros, muchas veces los más próximos, y todas las formas de agresión que no consisten en violencia sobre los cuerpos, podemos llamar con propiedad oscura y terrible a esta primera etapa en que estamos, que no ha cambiado desde los orígenes en esos aspectos básicos. Simplemente, estamos habituados a sus rasgos. Y se insiste torpemente en que esos rasgos son propios de la naturaleza humana, para añadir en seguida que con todo estamos en el mejor de los mundos posibles. 


\section{LÍNEAS DE PROGRESO HACIA LA PLENA HUMANIDAD}

A partir de esta situación hay una sugestiva manera de enfocar el curso conocido de la historia si lo reducimos a sus trazos más gruesos (y así podemos extraer unas conclusiones esclarecedoras acerca del "progreso» en el que los occidentales nos creemos instalados). Es esperanzadora la metáfora de que el lenguaje tiene tendencia a repararse a sí mismo (a ir eliminando sus efectos disfuncionales). Como consecuencia del desarrollo del argumento moral poco a poco se han ido estableciendo numerosos espacios en que es impensable que el que tiene más fuerza trate de imponerse empleando la violencia física. Y esto demuestra que los rasgos de la cultura bárbara pueden ser inhibidos si se insertan en un sistema semiótico que modifique sus causas. Contemplando el desarrollo histórico con alguna confianza en tiempos mejores podemos apreciar un camino de autodepuración que da espacio a progresos cognitivos, morales y políticos, y a razones contra los despropósitos y las graves patologías colectivas. La historia de este progreso se inició en tiempo remoto, cuando la razón filosófica se enfrentó a la superstición mediante la crítica a las creencias tradicionales sin fundamento, afirmando que el humano es un sistema material, que los humanos somos iguales por naturaleza unos a otros, y que la creencia en dioses y almas carece de fundamento.

Son muy antiguas las primeras manifestaciones conocidas de la concepción del humano como un sistema material perecedero, que se vienen sucediendo al menos desde fines del tercer milenio antes de Cristo en Egipto y Babilonia. En la India la doctrina lokayata tenía ya a mediados del primer milenio a. de C. una concepción de todo lo existente, el hombre incluido, como formado por organización de elementos y abocado a desorganizarse con la muerte en esos mismos elementos. Desde esta posición se criticó la teoría de la transmigración de las almas y a esto se añadió más tarde el postulado de que el movimiento, el espacio y el tiempo son propiedades de la materia. En China se encuentran doctrinas materialistas en Mo-tse y en el taoísmo, y también en algún confuciano como Xun Zi.

La corriente materialista está también presente en la escuela de Mileto, pero su formulación más interesante se debe a Demócrito, para quien el alma, como las restantes cosas, está formada por átomos y desaparece con el organismo tras la muerte. A partir de entonces la lista de filósofos occidentales materialistas es amplia (entre ellos B. Talesio, G. Bruno, Galileo, Bacon, Hobbes, Gassendi, Locke, Spinoza, La Mettrie, Helvecio, Holbach, Diderot, Feuerbach, Engels y Marx). En el terreno de la filosofía política sofistas como Alcidamante e Hipias de Elis expusieron que, de la misma manera que la naturaleza no ha hecho a nadie esclavo, tampoco ha hecho a nadie noble, y que por ello es injustificable la aristocracia de nacimiento. Estas personas reflexivas cayeron en la cuenta de que la desigualdad social no es otra cosa que la consecuencia de la fuerza violenta (tome luego la forma que tome, incluso la forma de ley, porque las leyes, dice Hipias, siempre oprimen a los débiles).

Por lo que se refiere a la religión, tanto la concepción materialista como la comparación de la diversidad de invenciones supersticiosas condujo en tiempos remotos con toda naturalidad al ateísmo. Eran ateas la doctrina lokayata y la doctrina de Xun $\mathrm{Zi}$, y lo fueron algunos filósofos griegos, que, porque conocían las civilizacio- 
nes de Persia, Babilonia y Egipto, y además pueblos en fases más primitivas, como los escitas y los tracios, y porque pertenecían a un pueblo sin sacerdocio encargado de inculcar la fe religiosa desde la nińez, pudieron acceder al fácil razonamiento de que todas las religiones son supersticiones equivalentes, que han surgido y se han propagado siguiendo pautas parecidas. Quienes al mismo tiempo supieron observar el papel social que juega la religión, llegaron a la conclusión que expone Critias de que es invento de un hombre astuto y prudente para someter a los hombres a las leyes por medio del temor.

\section{LA ACTITUD REACCIONARIA}

Una vez ocurridos estos momentos de lucidez, la defensa del elitismo no es ya meramente la legitimación del impulso natural del fuerte que los demás aceptan, como era en los inicios. Es ya una reacción contra el progreso cognitivo habido, es un discurso reaccionario. Y afirmar la existencia del alma y de los dioses, o de un único dios, no es ya una espontánea explicación supersticiosa de lo desconocido, sino una reacción a la idea conquistada de que no es necesario postular arbitrariamente entidades espirituales para explicar el mundo y el comportamiento humano, ni para defender los valores morales. Las creencias dualistas pueden seguir siendo inocentes entre gentes poco reflexivas, pero no su defensa teórica. Como pensamiento reaccionario, esa defensa carece ya de la espontánea ingenuidad de la creencia primitiva.

En este sentido cabe decir que no toda filosofía ha sido liberadora, pues muchos filósofos han trabajado para reconstruir una vez y otra el discurso legitimador, muy apreciado en su papel de acompañar o sustituir a la religión en la misión amparadora del elitismo.

\section{Progresos Relativos}

1. Los progresos de la razón y la justicia han adquirido las siguientes formas institucionalizadas:

a) El desarrollo científico que nos permite entender mejor los procesos naturales y que, en consecuencia, se enfrenta a la superstición y crea dificultades a la mentira pública. El método de la ciencia moderna garantiza que, por abstractos que sean los conceptos teóricos, no dejen en ningún momento de anclarse a la realidad, advirtiéndonos de cualquier desviación metafísica en tesis que pretenden ser empíricas.

b) La moral presente en doctrinas como las de Buda y Cristo, en las que se resume una línea de aprendizajes acerca del error de quien cree que conseguirá la felicidad por el camino de la ambición, la mentira, la violencia y la crueldad. Del egoísmo violento y sus resultados se ha extraído el aprendizaje moral de que los humanos deben tratarse unos 
a otros benévolamente (incluso con la extensión de ese comportamiento a los animales o, al menos, a los que más se asemejan al humano). Los ideales de igualdad, libertad y fraternidad, proclamados en la Revolución Francesa, van en esta línea.

c) Como derivada de las anteriores, la convicción de que la legitimación de la ley y de las instituciones debe adquirir naturaleza racional a partir de la convicción de que todas las personas tenemos los mismos derechos, de que no hay súbditos, sino ciudadanos. La consecuencia ha sido la transformación del Estado, desde el absolutismo teocrático a lo que se entiende por democracia contemporánea.

2. Hay sin embargo que situar estos progresos en una justa perspectiva:

a) El desarrollo científico sólo ha ocupado el espacio de los objetos naturales, mientras en el espacio social la ciencia apenas comenzada está eficazmente estorbada por diferentes actitudes ideológicas. Supersticiones y mentiras siguen dominando el espacio de los objetos sociales (persona y sociedad), que es al fin y al cabo el espacio más importante en el contexto político. Muchos de nuestros coetáneos, incluso pertenecientes a las élites intelectuales, creen los dogmas religiosos y practican sus ritos, e incluso rinden algún tributo a conocimientos supersticiosos menos reputados (toman en serio los horóscopos, pagan para que les echen las cartas, consultan a videntes profesionales y se impresionan ante historias de poderes paranormales).

Por otra parte, el progreso científico conseguido no funciona en la población en general, sino que los distintos conocimientos pertenecen, a trozos, a distintas comunidades de especialistas, lo que no es obstáculo para que los resultados de la tecnología lleguen a todos (o al menos a los que pueden pagar). Cualquier ciudadano sabe pulsar el mando a distancia para encender su televisor, no importa que ni sepa ni tenga curiosidad por saber por qué se ven imágenes en la pantalla. Por ello el concepto de sabiduría tiene una referencia incierta. Si el título de sabio, que se suele otorgar al filólogo, al historiador o al científico natural, se lo negamos a quien conserva una idea tradicional de la persona por más que sea creativo en física teórica, y si consideramos que la sabiduría requiere conocimiento suficiente de todo el campo de la ciencia y, además, una estructura afectiva que permita incorporar ese conocimiento a la vida de manera armoniosa, entonces el uso del término «sabiduría» debería quedar en suspenso hasta que los sociólogos investiguen si hay sabios en la tierra, pues muchos de los llamados sabios son meramente brillantes expertos unidimensionales que sólo han desarrollado sus capacidades en un pequeño campo.

b) En cuanto al progreso moral, no está tan claro dónde funcionan los valores proclamados, aunque parece evidente que no funcionan en muchos ciudadanos a la hora de orientar su comportamiento. Proclamar la 
igualdad y la fraternidad en un sistema elitista es, como mínimo, una contradicción. La idea de fraternidad universal no es universal y con frecuencia no es efectiva allí donde se adopta formalmente. Dicho de otra forma, de nuestra fábrica social salen demasiadas personas con la afectividad mal dispuesta y con poca capacidad cognitiva e imaginativa, cuya conducta no se guía por la fraternidad y la solidaridad con los restantes habitantes de la tierra, sino por el deseo de obtener ventajas personales. En los países más desarrollados son muchos los que verían con buenos ojos que se aplicara el viejo principio del «ojo por ojo» o la privación de los derechos de ciudadanía a quien comete un delito que concita la indignación general. La pena de muerte sigue siendo practicada en un país como Estados Unidos porque la mayoría de la población la defiende.

c) Las democracias existentes reconocen derechos individuales y limitan o mitigan los abusos a que tiende el poder. En ese sentido se puede decir que son un progreso, porque preferimos que nos exploten y engatusen a que nos torturen y asesinen. Pero a continuación hay que añadir que este tipo de democracia no se ha extendido a todos los pueblos de la tierra, ni sus principios son aceptados por todos los habitantes de los pueblos que la practican. Persisten Estados teocráticos o dictatoriales y son numerosos los ciudadanos que dentro de los Estados llamados democráticos querrían que las iglesias fueran políticamente más influyentes, los que quieren que se interrumpan, incluso manu militari, procesos democráticos que toman un camino contrario a sus propias convicciones, o los que, lisa y llanamente, afirman que se vive mejor bajo una dictadura. Sólo por ello ha sido posible que en el mismo solar de nuestra cultura se hayan desarrollado fascismos de espantosos resultados. Esos fascismos siguen teniendo muchos partidarios y su número podría aumentar en circunstancias favorables.

Por otra parte la democracia en sistemas elitistas es siempre plutocracia disfrazada. Por detrás de las apariencias, las élites políticas reciben la adecuada recompensa en la medida en que sirvan, ante las masas, de testaferros y de elementos legitimadores de un poder más fuerte y oculto, el de las élites económicas, algo inevitable cuando no hay límite legal para la riqueza privada y el mercado va dando más a quienes más tienen $\mathrm{y}$ menos a quienes tienen menos.

\section{ILUSTRACIÓN Y POSMODERNIDAD}

Ha habido intentos de conseguir una sociedad que hiciera reales para todos sus miembros los ideales de la libertad, la igualdad y la fraternidad. Revoluciones como la francesa del xviı o la soviética del xx tenían esa pretensión, pero en seguida fueron neutralizadas por la tendencia elitista, a la que la mayoría de la población volvió en seguida. El resultado de las revueltas y revoluciones de los dominados ha tenido siempre la característica de que, incluso cuando ha supuesto pasos adelante 
(de aproximación a una sociedad en la que sea mínimo el grado de dominación y explotación), no ha roto con el modelo de sociedad clasista y no ha encontrado por tanto la salida a un mundo racional y justo.

Entretanto algunos teóricos interpretan los ideales de la modernidad como el propósito de imponer los valores propios del varón blanco euronorteamericano al resto del mundo sin reconocer sus diferencias, más bien decretando su inferioridad, y llegan a pensar que los fundamentalismos son una forma no tanto de premodernismo como de posmodernismo. Así interpretado, el fundamentalismo islámico repudiaría la modernidad como un arma de la hegemonía euroestadounidense, y condenaría al modernismo clásico como una fuerza puramente occidentalizadora. Por este camino se puede llegar a la artificiosidad a que llega, por ejemplo, Homi Bhabha cuando critica la dialéctica identificándola con las divisiones binarias, y cree que las identidades esenciales y la totalización que reprime las diferencias es la forma en que actúan las fuerzas de opresión social. De lo que se sigue que el proyecto político poscolonial consistiría en afirmar la multiplicidad de las diferencias para poder subvertir el poder de las estructuras binarias dominantes.

Creo que es menos artificioso y más ajustado a los hechos concebir la modernidad que desemboca en la Ilustración como el deseo utópico de que sea la razón, aliada a la empatía fraternal, la que regule los asuntos humanos, siendo entonces el marxismo una de sus derivaciones, cuya aspiración de liberación se extiende a mujeres, no blancos y no euroestadounidenses. Esto es, la apelación ilustrada a la razón pretende que la humanidad entera salga de la edad bárbara en que se encuentra y ello requiere que la mayor parte de la población (incluida en ella la mayor parte de la población masculina, blanca y euroestadounidense, que bien lo necesita) se transforme en los espacios del conocimiento y del afecto. Si tal cosa se consiguiera algún día, habría una uniformidad consistente en que casi todas las diferencias culturales, debidas sobre todo, no lo olvidemos, a la diferencia de religiones y de afectividades (unas sanas, muchas más patógenas), habrían desaparecido. En las gentes se sustituirían las diferentes supersticiones religiosas por el mismo conocimiento científico y las malas por buenas disposiciones hacia los demás. Entonces, de la misma manera que habría desaparecido el yugo a las supersticiones islámicas, habrían desaparecido los yugos a las supersticiones judía y cristiana. No se trata por tanto de una perspectiva eurocéntrica o etnocéntrica. Si bien un efecto sería acabar con numerosas diferencias culturales y étnicas, ello no es de lamentar, pues se trata de persistencias desdichadas. No echaremos de menos que desaparezca la diferencia que consiste en la ablación de las niñas, como no echamos de menos que haya desaparecido la diferencia que consistió en ofrecer sacrificios humanos a un dios terrible. Tampoco lamentaremos que desaparezcan las desigualdades producidas por la racionalidad económica que se atribuye al mercado. Eliminadas las diferencias que separan e incomunican a los humanos, formaríamos todos una comunidad mundial que podría conservar la múltiple belleza acumulada en las distintas culturas históricas y que liberaría además nuevas fuerzas creativas.

En la mala interpretación de la Ilustración influye que de ordinario se identifica ciencia con racionalidad técnica y ello se contrapone a la subjetividad, al deseo, a la vitalidad como fenómeno psicológico autónomo. Se olvida entonces que, den- 
tro de la ciencia, y por lo que concierne a un proyecto de liberación, el papel fundamental corresponde a la ciencia social, de la que hemos de esperar las herramientas para una adecuada fábrica del individuo, sin la cual ningún proyecto de liberación puede dar pasos definitivos al frente.

Teniendo esto en cuenta hay que reiterar que no hemos comenzado una nueva era por mucho que la tecnología haya avanzado hasta donde lo han hecho la informática actual, la investigación biogenética, la astrofísica o la nanotecnología, porque hay un profundo desajuste entre el conocimiento científico distribuido por diferentes comunidades de expertos y el conocimiento que maneja la población tomada individuo a individuo. Los autores que se han deslumbrado al contemplar los efectos de la Red de redes no parecen percibir que las cosas básicas siguen como siempre. Los procesos de socialización, de los que dependen los tipos de mentes que se conectan a la Red, siguen siendo dependientes de un orden social adverso y de viejas recetas pedagógicas ajenas al desarrollo científico. La modernidad sólo ha existido como un buen deseo, y desde luego sus virtudes no se han generalizado con la Red. Esa generalización es algo que está por venir y por lo que hay que seguir luchando.

A ella se opondrán con toda su fuerza las élites actuales, promotoras y defensoras de la forma presente de cultura bárbara, ayudadas de su formidable ejército de militares, teóricos, políticos y comunicadores, cuyo arsenal comprende políticas y represalias económicas, descalificaciones y acciones legales y bélicas que cegarán la vía de progreso moral mientras no haya una insurrección mundial y efectiva. Ello exige que aumenten las dosis de lucidez desparramadas por el mundo. 


\section{BIBLIOGRAFÍA}

Berger, P.L. y Luckmann, T. (1966): La construcción social de la realidad. Buenos Aires, Amorrortu, 1972.

Chamorro, J.M.: Lenguaje, mente y sociedad: hacia una teoria materialista del sujeto. Servicio de Publicaciones de la ULL, 2007.

Chamorro, J.M.: Positivismos y Antipositivismos. La herencia del siglo XX. Servicio de Publicaciones de la ULL, 2009.

Chamorro, J.M.: Capitalismo, izquierda y ciencia social. Hacia una renovación del marxismo. Gavagai, 2019.

Harris, M. (1968): El desarrollo de la teoría antropológica. Historia de las teorias de la cultura. Siglo XXI, 1979.

Harris, M. (1985): Jefes, cabecillas, abusones. Alianza Editorial, 1993.

Mead, G.H. (1934): Espiritu, Persona y Sociedad. Barcelona. Paidós, 1953.

Veblen, Th. (1944): Teoría de la clase ociosa. FCE, 1998.

Vigotski, L.S. (1934): Pensamiento y lenguaje. Buenos Aires, la Pléyade, 1983.

Whitehouse, H. et al.: Complex societies precede moralizing gods throughout world history. Nature, 2019. 
